\title{
Názory trenérů lyžařů běžců na přípravu ve vyšší nadmořské výšce
}

\section{Questions regarding high altitude in preparing cross country skiers}

\author{
Martina Chrástková, Jiří Suchý
}

Fakulta tělesné výchovy a sportu Univerzity Karlovy, Praha

\begin{abstract}
Abstrakt
Problematika využití př́pravy ve vyšši nadmořské výšce pro sportovní výkony v běhu na lyžích je velmi diskutovaným tématem trenérů, závodníků i jiných odborníků. Základní poznatky publikované $v$ odborné literatuř jsou stručně shrnuty v teoretické části článku. Hlavní část práce uvádí praktické poznatky a zkušenosti s touto problematikou úspěšných trenérů běhu na lyžích, jež byly zjištěny na základě kvalitativního strukturovaného rozhovoru sotevřenými otázkami. Všichni dotazovaní $v$ podstatě potvrdili principy aklimatizace na vyšši nadmořskou výšku uváděné v odborné literatuře. Řizené rozhovory prinášejí podle našeho názoru některé zajímavé postřehy, které dosud nebyly publikovány.
\end{abstract}

\begin{abstract}
Questions regarding higher altitude training application of performance in cross country skiing is much discussed theme of coaches, sportsmen and other specialists. Elemental pieces of knowledge in literature are summarised in theoretical section of article. Mean part of this thesis present practical knowledge and experiences of successful trainers of cross country skiing. Answers have been detected during qualitative structured interview with open questions. All respondents have confirmed principles of acclimatization to higher altitude which are presented in literature. Controlled interviews are very interesting and from my point of view bringing some information which have not been published.
\end{abstract}

Kličová slova: vyššínadmořská výška, vrcholový sport, běh na lyžích, specifika tréninku ve výšce, strukturovaný rozhovor

Key words: $\quad$ higher altitude, top-level sport, cross - country skiing, specifics of training in altitude, qualitative structured interview

Výzkum byl podpořen z prostředků výzkumného zámèru MSM0021620864 a specifického vysokoškolského výzkumu 2011-263602.

\section{Úvod}

V současné době je jednou z nejčastěji diskutovaných legálních možností ke zvyšování sportovní výkonnosti využívání tréninku v prostředí s nižším parciálním tlakem vzduchu. Fyzikální i klimatické podmínky vyšších nadmořských výšek kladou, ve srovnání s nížinou, na organismus vyšší nároky jak při pobytu, tak tréninku. Zařazení různých forem tréninku a pobytu ve vyšší nadmořské výšce je pro lyžaře běžce nezbytnou součástí celoroční přípravy. Obecně je tento způsob tréninku považován za jeden ze základních prostředků rozvoje sportovní výkonnosti.

Přestože je v současné době publikováno relativně značné množství prací zabývajících se touto tématikou, stále nejsou všechny otázky tréninku za využití nižšího parciálního tlaku vzduchu zodovězeny. Shoda při posuzování užitku této formy tréninku existuje ve dvou směrech:

- prríprava na soutěže, jež proběhnou ve vyšší nadmořské výšce,

- využití vyšší nadmořské výšky pro soutěže v nížině (Dovalil a kol. 1999).

Na úrovni vhodné nadmořské výšky pro vysokohorskou přípravu se odborníci shodují. Jedná se o výšku v rozmezí 2100 až 2500 m n. m. Lychatz (Lychatz 1990, Suchý; Dovalil 2009) při využívání kyslíkových stanů a barokomor je vhodné postupné zvyšování simulované výšky. K této problematice je v sou- 
časnosti k dispozici velké množství poznatků (např.: Vaněk 1968, Choutka a Urbánek 1968, Jokl 1968, Fibinger a Novák 1986, Fuchs a Reiss 1990, Wilber 2004, Suchý a Dovalil, 2005, 2009, Suchý a kol. 2009). Všechny publikace se shodují, že případné chyby v koncepci a následné realizaci hypoxického tréninku vyvolají v organismu sportovce větší reakce, v jejichž důsledku dochází k rychlejšímu nástupu přetížení, ve srovnání s tréninkem v nížině. $Z$ toho plyne, že nadmořská výška klade zvýšené nároky nejen na sportovce, ale též na trenéry a celý realizační tým.

V souladu s dalšími literárními zdroji Suchý a kol. (Suchý a kol. 2009) uvádějí, že k vlivu nadmořské výšky na organismus sportovců většiny vytrvalostně zaměřených sportovních odvětví existuje řada publikací. Tyto studie se však zabývají především fyziologickými a psychickými aspekty vysokohorského tréninku. Naopak informace, jež by shrnovaly názory a empirické zkušenosti trenérů či sportovců s touto problematikou, prozatím př́liš publikovány nebyly. Suchý a Dovalil (2009) realizovali strukturované rozhovory s otevřenými otázkami s úspěšnými trenéry a sportovci z různých letních sportů (triatlon, moderní pětiboj a fotbal). $\mathrm{Z}$ tohoto šetření vyplynulo, že trénink ve vyšší nadmořské výšce se v posledních letech stal nezbytnou součástí tréninkového procesu především vytrvalostních sportovních odvětví. Abychom názory trenérů a sportovců letních sportů doplnili, rozhodli jsme se oslovit trenéry běhu na lyžích, vytrvalostního sportu, kde je trénink ve vyšší nadmořské výšce nezbytností.

\section{Výzkumný problém}

Zjistit názory a př́stupy úspěšných českých trenérů běhu na lyžích na problematiku tréninku ve vyšší nadmořské výšce. Konfrontovat zjištěné poznatky s odbornou literaturou, jejíž stručné shrnutí obsahuje teoretická část článku.

\section{Úvod}

Kapitola shrnuje základní aspekty vyšší nadmořské výšky z pohledu řízení sportovního tréninku, které mají úzký vztah k otázkám v řízeném rozhovoru.

$S$ přibývající nadmořskou výškou klesá tlak vzduchu podle vzorce vertikálního barického gradientu na 100 m výšky o:

\section{$\stackrel{r}{\nabla} p=\frac{\partial p}{\partial n}$}

S tlakem vzduchu progresivně klesá také parciální tlak kyslíku obsaženého ve vzduchu. Nezávisle na zeměpisné šiřce s nadmořskou výškou také klesá teplota, a to přibližně o $0,6^{\circ} \mathrm{C} / 100 \mathrm{~m}$ (teplotní gradient). Zeměpisné souřadnice dané lokality ale výrazně ovlivňují denní a sezónní kolísání teploty (www. geogr.muni.cz).

V horském studeném vzduchu je tlak vodních par snížen a na každých 1000 m výšky klesne přibližně o $25 \%$. Kombinace relativně nízké vlhkosti a nízké teploty vzduchu může být subjektivně velmi nepř́ijemná (Sherry a Wilson 1998, Suchý a Dovalil, 2009). Ve vyšší nadmořské výšce je tenčí vrstva atmosféry, která je schopna pohltit nižší množství slunečního záření, především dlouhovlnného záření. Množství ultrafialového záření, které dopadá na povrch země se na každých 1000 výškových metrů zvyšuje o 20 $30 \%$. Riziko nežádoucích účinků tohoto záření, především na oči a kůži, se tak výrazně zvyšuje.

Pupiš a Korčok (2007) se zabývají pojmovou nejednotností výšky ve sportovní př́ípravě. Někteří autoři (např̀. Görner a Kompán 2001, Štulrajter et al. 2001, Paugschová a kol. 2006, Kobela 2007) pro trénink ve vyšší nadmořské výšce využívají termínu středněhorská příprava. Suchý a Dovalil (2005) používají termín vysokohorské prostředí, který zřejmě vychází z anglických publikací (např. Bigard et al. 1991, Suslov 1994, Friedmann a Burtsch 1997, Levin a Stray-Gundersen 1997), kde je označováno jako „high altitude“. Pupiš a Korčok (2007) využívají termín „hypoxická př́íprava“.

Existuje množství přístupů dělení středisek hypoxické přípravy. Suchý a Dovalil (2005) rozlišují nadmořskou výšku na: 
- nízkou: od hladiny moře do $800 \mathrm{~m} \mathrm{n}$. $\mathrm{m}$.

- střední: od 800 do $1500 \mathrm{~m} \mathrm{n.} \mathrm{m.}$

- vysokou: od 1500 do $3000 \mathrm{~m} \mathrm{n}$. m.

Jiné rozdělení uvádí Suslov a kol. (Suslov a kol. 1999) či Korčok s Pupišem (2006, 2007), kteří pro potřeby vrcholových sportovců uvádí 3 základní stupně nadmořské výšky:

- nízký stupeň: do $1300 \mathrm{~m}$ n. m.

- $\quad$ střední stupeň: od 1300 do $2500 \mathrm{~m} \mathrm{n.m.}$

- $\quad$ vysoký stupeň: nad $2500 \mathrm{~m}$ n. m.

Před nástupem adaptačních změn ve výšce může být srdeční odezva a tepová frekvence na pohybovou aktivitu ve stř̌ední intenzitě (v průběhu i po skončení) o 20 - 30\% vyšší ve srovnání s nížinnými polohami. U neadaptovaných jedinců se snižuje úroveň maximální spotřeby kyslíku $\left(\mathrm{VO}_{2 \max }\right)$ přibližně o $9-$ $11 \%$ na každých $1000 \mathrm{~m}$ (Wilber 2004).

Podle Reevese (1992) jsou u neadaptovaných jedinců v prvních dnech tréninku ve vyšší nadmořské výšce výrazně zvýšené hodnoty tepové frekvence a koncentrace laktátu v krvi při stejné intenzitě zatížení jako v normoxii.

Adaptace na výšku jako komplexní proces trvá přibližně 21 dní. Většinou se aklimatizace dělí na tři fáze: akomodace, adaptace a aklimatizace. Aklimatizační procesy pozitivně ovlivňuje úroveň trénovanosti a předchozí zkušenosti (Dovalil a kol. 1999, Suchý a Dovalil 2009).

Trénink ve vyšší nadmořské výšce musí být plánován s maximálním ohledem na zákonitosti regeneračních procesủ, $v$ př́ípadě potřeby je vhodné neplánovaně zařadit odpočinkový den. Přibližně pátý den pobytu je tř̌eba redefinovat aktuální hodnoty jednotlivých intenzit zatížení, nebot se velice liší od hodnot v normoxii. Ani ve fázi reaklimatizace není výkonnost stabilní. Její průběh má vlnovitý průběh (např. Fuchs a Reiss 1990, Suchý a Dovalil 2009). Optimální výkonnost lze očekávat v rozmezí 3 - 4 dnů okolo 21. dne po návratu $\mathrm{z}$ vyšší nadmořské výšky. Po $5-6$ týdnech normoxie pozvolna mizí pozitivní efekty tréninku v nadmořské výšce (Wilber 2004).

Existují tři možnosti jak dosáhnout podmínek nižšího parciálního tlaku vzduchu:

- tradiční tréninkové kempy a pobyty ve vyšších nadmořských výškách,

- umělé hypoxické prostředí (hypoxické stany, barokomory),

- kombinace obou výše jmenovaných alternativ.

Všechny trři alternativy účinkují $\mathrm{v}$ zásadě stejně. Rozdílnost spočívá $\mathrm{v}$ možnostech provádět vlastní pohybovou aktivitu, dále pak v časových, ekonomických, organizačních a psychických nárocích př́rodního versus uměle vytvořeného hypoxického prostředí (Suchý 2009, Suchý a Dovalil 2009).

Pravidelná analýza krve je nedílnou součástí tréninku, a to nejen ve výšce. Trénink a pobyt ve výšce by měl být kontrolován testy: parciální tlak kyslíku v krvi, úroveň hemoglobinu (zvláště oxyhemoglobinu), hladina železa v krevním séru. Dále pak proměnné, které charakterizují acidózu po zatížení (Weineck 1997, Sherry a Wilson 1998). Průběh adaptace lze účinně sledovat hodnocením průběhu zotavení, především tepové frekvence.

Velmi často je diskutována otázka: bydlet nahoře a trénovat dole, nebo bydlet dole a trénovat nahoře, či bydlet i trénovat nahoře? Madsen (1999) tvrdí, že pro lepší výkonnost při soutěžích v nížině je vhodnější bydlet (spát) ve vyšší nadmořské výšce a trénovat $\mathrm{v}$ nížině. Naopak adaptační změny pro růst výkonnosti ve vyšší nadmořské výšce vznikají spíše při variantě: trénovat nahoře a bydlet dole. Při pobytu v nížině dochází k rychlejším regeneračním procesům (Terrados 1995).

\section{Metodika}

Pro získání informací byl zvolen strukturovaný rozhovor s otevřenými otázkami. Tato kvalitativní metoda sice nevykazuje pružnost při sondování, ale její předností je minimalizace variace otázek (Patton 1990, Hendl 2005).

V úvodu dotazování byly kladeny otázky jednodušší, na něž navazovaly komplikovanější. Závěrečná otázka se později ukázala jako vhodně formulovaná, nebot odpověd’ na ni plynule přešla v neformál- 
ní dialog, kterým bylo interview zakončeno. Dle charakteru byly takto neformálně získané informace zohledněny v již zodpovězených otázkách.

Většina rozhovorů byla uskutečněna během zimních víkendů roku 2010, kdy se konaly lyžařské běžecké závody. Čtyři rozhovory byly provedeny elektronickou poštou, nebot's trenéry působícími v zahraniční (2) a také předními českými (2) se nebylo možno osobně setkat.

Celkem bylo provedeno 11 strukturovaných rozhovorů s trenéry dorosteneckých kategorií (J. Ilavský, M. Kovačič, J. Teplý, D. Schreier, J. Kubica) a dospělých (P. Honzl, M. Petrásek, K. Žalč́ik, V. Šlofar), působících v Česku a s dvěma trenéry působícími v zahraničí (V. Klimková (SVK) a R. Duda (AUT)). Výběr trenérů byl koncipován tak, aby pokud možno zohlednil zkušenosti trenérů, kteří pracují s mládežnickými kategoriemi i seniory.

Otázky pro realizaci kvalitativního strukturovaného rozhovoru vycházely $\mathrm{z}$ obdobného šetření Suchého a Dovalila (2009):

- Využíváte při tréninku vyšší nadmořskou výšku?

- $\quad Z$ jakých zdrojů jste čerpal informace $k$ tréninku ve vyšší nadmořské výšce?

- Jaký model př́ípravy ve vyšší nadmořské výšce v rámci RTC obvykle využíváte?

- Používáte hypoxické stany - barokomory? Respektive, používal byste je, kdybyste nebyl omezen finančně?

- Jak zajištujete, aby nebyli svěřenci při tréninku ve vyšší nadmořské výšce přetíženi? Použiváte v normoxii rozbory krve?

- Jaký máte názor na trénink ve vyšší nadmořské výšce?

- Přikláníte se spíše k variantě „train low - live high“, nebo „train high - live high“, nebo „train high - live low"?

- Jaké jsou Vaše osobní zkušenosti s tréninkem ve vyšší nadmořské výšce?

Předmětem šetření bylo získání praktických aspektů tréninku běhu na lyžích, proto jsme se podrobněji nezabývali sumarizací zdrojů informací k této problematice.

\section{Výsledky}

Z informací, jež jsme získali na základě strukturovaného rozhovoru s otevřenými otázkami vedeným s jedenácti úspěšnými trenéry lyžařů běžců, jsme dospěli k následujícím závěrům:

\section{Využití vyšší nadmořské výšky}

Všichni oslovení trenéři lyžařů běžců se shodli, že trénink ve vyšší nadmořské výšce je pro běžce na lyžích nezbytný.

Pro žákovské a dorostenecké kategorie bohatě dostačují stř̌ední výšky okolo 1000 - $1400 \mathrm{~m}$ n. m., které jsou dostupné i v ČR (Černá hora a Horní Mísečky v Krkonoších, Praděd v Hrubém Jeseníku, Boží Dar v Krušných horách, Zadov na Šumavě, apod.). Navíc se jedná o lokality, kde je v ČR sníh nejdřive a mládežnické týmy sem jezdí na první lyžování, aniž by si výšku uvědomovaly.

Pro starší závodníky (junioři, dospělí) je prríprava ve vyšší nadmořské výšce nezbytná, a to ve výškách od 1400 m n. m. a výše: Štrbské Pleso (SVK; 1350 m n. m.), Livigno (ITA; 1800 m n. m.), Tauplitz (AUT; 1700 m n. m.), Obertilliach (AUT; 1700 m n. m.), Dachstein (AUT; 2600 m n. m.), Belmeken (BUL; 2050 m n. m.), Davos (SUI; 1560 m n. m.) a další.

\section{Znalosti problematiky tréninku ve výšce}

V začátcích tréninku lyžařů běžců ve vyšší nadmořské výšce (na začátku 70. let minulého století) tehdejší trenéři reprezentace využívali poznatků veslařủ a dráhových cyklistů. Běžci na lyžích začali využívat vyšší nadmořskou výšku jako třetí sportovní odvětví v ČR, právě po veslařích a dráhových cyklistech. Dlouholeté zkušenosti si trenéři předávají mezi sebou.

Při hledání nových poznatků k problematice se dřive trenéři obraceli na publikace vydané v tehdejším SSSR a NDR. V dnešní době svou pozornost obrací na norské, finské, německé či americké webové servery nebo publikace a jejich překlady. Též přebírají informace a zkušenosti od atletů. 
Velkou roli při získávání informací též hrála roli Ústřední tělovýchovná knihovna na FTVS UK či databáze ČSTV Sportis.

Slovenští trenéři uváděli konkrétně publikaci Hamara a Liptákové (Hamar a Liptáková 1998).

\section{Model přípravy ve vyšší nadmořské výšce}

Dotázaní trenéři se sice svými odpověd’mi shodovali v názoru na délku pobytu ve vyšší nadmořské výšce, která je i literaturou doporučována, tedy 20 až 22 dní, $4-5 \mathrm{x}$ za rok, avšak z důvodů finančních a psychických, nemocnosti, školních povinností hledají jiné modely, obvykle s kratší délkou trvání.

Většinou se shodují na délce pobytu 10 - 12 dní, prrípadně 16 dní dvakrát v letním prrípravném období a jednou v zimním, jako závěrečná příprava na vrchol sezóny. Nejčastěji je využíván režim tří tréninkových dní a jednoho dne volna.

$\mathrm{V}$ roce 2000 se reprezentačnímu družstvu žen osvědčil model 5 x 7 dní ve výšce se sedmidenním odpočinkem v nížině s důslednou regenerací a postupným tréninkem. Tento výškový trénink probíhal od konce srpna do začátku listopadu. První dva pobyty byly zaměřeny na vysokohorskou turistiku a dlouhá imitační cvičení na sjezdovkách ve $2000 \mathrm{~m} \mathrm{n}$. m., další 3 pobyty se ze $70 \%$ odehrávaly na Dachsteinu a ze $30 \%$ v Ramsau. Nadcházející sezóna byla z pohledu výsledků pro ženy úspěšná, což naznačuje, že tento model byl zvolen vhodně. Avšak každé př́ípravné období je jiné, a proto nelze stále opakovat jeden tréninkový model.

Všeobecně se v literatuře doporučuje po př́ijezdu do výšky tréninkovou intenzitu snížit a první $3-4$ dny trénovat jen $\mathrm{v}$ aerobním pásmu. Snížený by měl být i objem tréninku. Někteří z dotázaných uvedli, že využívají model, kdy první den se závodník zapracuje a druhý a třetí den absolvuje těžké tréninky. Následuje den volna a tréninkové dny zaměřené na adaptaci a regeneraci. Pro potřeby závodů ve vyšší nadmořské výšce se trenéři se sportovci snaží zajistit ubytování v nížině a jen na samotnou dobu trvání soutěže se přesunují do výšky. Pokud tento model z technických důvodů není možné aplikovat, pak se shodují na př́jezdu do výšky 2 až 3 dny před konáním soutěže. Optimální je samozřejmě pobyt ve výšce $\mathrm{v}$ rozsahu dvou mikrocyklů před konáním soutěže. Zajímavostí desetidenního pobytu ve výšce je poznatek některých trenérů, že první dva až tři dny pobytu ve výšce ještě organismus nevykazuje takovou reakci na změnu nadmořské výšky. $Z$ těchto důvodů zařazují v tyto první dny intenzivní trénink, na který ovšem musí následně navázat 4. až 7. den důsledné snížení objemu i intenzity a regenerace.

\section{Využití hypoxických stanů}

Zkušenosti s hypoxickými stany měli jen dva z dotazovaných. Jeden díky Kateřině Neumannové (1998 - 2002), která jej hojně využívala, a pomohl jí ke zvýšení výkonnosti. Pro využívání stanu je nutná vysoká psychická odolnost závodníka, aby se mohl adaptovat na úplně jiný režim tréninku. $\mathrm{V}$ těchto zařízeních není možné provozovat tréninkovou činnost. Kamila Rajdlová a Helena Balatková stany zkoušely využívat na podzim 2001, ale u nich se žádný kladný efekt neprojevil.

Druhý je ve své tréninkové praxi v 70. letech 20 . století se svěřenkyní B. Paulů testoval, ale nesetkal se s kýženým výsledkem, jen s velmi vysokou psychickou náročností. Proto od této metody rychle upustil a do př́pravy dále nezařazoval.

Většina z dotazovaných stany považuje za neetickou komerční záležitost, která slouží k zakrývání zneužití dopingu.

Všichni dotázaní trenéři preferují přirozeně navozenou vyšší nadmořskou výšku.

\section{Využití rozborů krve během př́ípravy}

Rozbory krve využívají především reprezentační družstva mužů a žen, která pravidelně spolupracují $\mathrm{s}$ biochemikem. Při vyšetřování krve sledují hladinu LA, CK, urey, hemoglobinu. Kluby na tuto spolupráci nemají finanční prostředky, a tak se trenéři musí spolehnout na jiné prostředky jak odhadnout efektivitu tréninku ve výšce: klidová, zátěžová a pozátěžová TF, uklidňování, pocity závodníka a chut do dalšího trénování, vizuální pohled (kontrola technického provedení pohybu, vizáž sportovců během tréninku i mimo zatížení), nechut' k jídlu, apod. 


\section{Názory na trénink ve vyšší nadmořské výšce}

Mezi trenéry běžců na lyžích je trénink ve vyšší nadmořské výšce všeobecně uznávaný. Všichni zastávají názor, že pro kategorie juniorů a dospělých je př́ímo nezbytný. Ovšem je nutné, aby závodník nebyl indisponován, zraněn, neměl náznaky nemoci a byl ochoten přistoupit na ztížené podmínky výšky, tzn. závodník musí být přesvědčen, že je vysokohorský trénink nezbytný. Trénink ve vyšší nadmořské výšce vyžaduje individuální př́ístup trenéra ke svěřencům, nebot každý na toto prostředí reaguje jinak (např. Květa Jeriová ve výšce mohla jen chodit, aby nedošlo k přetížení, zatímco jiní mohou absolvovat tréninkové zatížení stejné jako v nížině).

Při dodržení režimu čtyřikrát 10 až 12 dní ve výšce můžeme podle rakouských zkušeností očekávat zvýšení výkonnosti asi o 1 - 5\%. Naopak jeden z trenérů se setkal s velmi minimálním účinkem nadmořské výšky na koncentraci hemoglobinu v krvi reprezentantek.

\section{Varianty kombinace tréninku a pobytu ve výšce a v nižině}

V názorech na tuto problematiku se trenéři téměř neshodovali, což je v souladu s literaturou a záleží jaké cíle trénink ve vyšší nadmořské výšce sleduje. Lyžaři běžci tak využívají všech tří možností. Nejvíce trenérů se přiklání k variantě live high - train high v kombinaci s train low. Tento model je využíván především na podzim při soustředěních v Ramsau - Dachstein, kdy dopoledne probíhají tréninky na lyžích na ledovci a odpoledne se trénuje v nižší poloze v Ramsau: kolečkové lyže, imitace a běh. Dva z dotázaných byli pro variantu live high - train low a dva pro live low - train high.

Reprezentace mužů se při závodech snaží spát v nižší nadmořské výšce, naopak při výcvikových táborech preferují stejnou výšku jak pro pobyt, tak i na trénink.

\section{Osobní zkušenosti s vysokohorskou přípravou}

Pokud jsou dodrženy zásady o nepřetížení závodníka ve výšce, dobrý zdravotní stav, správný pitný režim, individuální přístup k závodníkům, tak je odezva na výšku většinou pozitivní. Pokud ovšem dojde k přetížení, nabourání vnitřní homeostázy, návrat k normálu je zdlouhavý a komplikovaný.

Nepř́ijemným úskalím tréninku ve výšce je především posun tepových zón při dané intenzitě v porovnání se zónami zjištěnými a ověřenými v nížině. Sportovec ve výšce nemusí ani dosahovat stejné hodnoty maximální TF jako v nížině. $Z$ těchto důvodů jsou sportovci náchylnější k přetížení.

Závodníci s nižší hladinou hemoglobinu v krvi mohou mít ve vyšší nadmořské výšce problémy (bolesti hlavy, únava atd.). Pokud tedy trenér dokonale nezná svého svěřence, může být překvapen negativní odezvou na tento typ tréninku.

Všichni dotázaní mají s tímto tréninkem pozitivní zkušenosti a jsou přesvědčeni, že je pro vrcholový běh na lyžích nezbytný, nebot i mnoho soutěží se odehrává ve vyšších nadmořských výškách.

\section{Diskuse}

Stále se potvrzuje naše domněnka, že neexistuje dostatečné množství studií zabývajících se problematikou tréninku ve vyšší nadmořské výšce (např. Friedmann a Burtsch 1997, Suchý a Dovalil 2009). Tento názor při rozhovorech nepř́mo potvrdili dotazovaní trenéři, kteří nové informace hledají na „obecných“ serverech světových lyžařských týmů. Všichni se ve svých odpovědích shodují, že pokud má mít pobyt nebo trénink ve výšce pozitivní efekt, je nutné důsledně individuálně přistupovat ke svěřencům a sledovat jejich fyziologické či biochemické změny.

Z odpovědí dotázaných vyplynulo, že trénink ve vyšší nadmořské výšce je nezbytné důsledně plánovat a tento plán operativně upravovat podle aktuálního stavu svěřence a nepřistupovat $\mathrm{k}$ němu mechanicky. Bohužel podle odpovědí trenérů lyžařů běžců neexistuje žádný obecně platný model tréninku ve vyšší nadmořské výšce, nebot každý závodník na tento model tréninku reaguje přísně individuálně. Sice trenéři ve svých odpovědích uváděli, že nejvhodnější doba pobytu ve výšce je okolo 20 - 22 dní, ale většina $\mathrm{z}$ nich ji nevyužívá a jezdí do výšky přibližně na 12 dnů, se snahou tento pobyt opakovat. Důvodem kratšího pobytu ve výšce jsou finanční, psychické, zdravotní aspekty i školní a pracovní povinnosti svěřenců. 
Čeští trenéři se svými odpověd’mi nepatrně rozchází s odbornou literaturou, když říkají, že pro mládežnické kategorie je pro adaptaci dostačující výška mezi 1000 a $1400 \mathrm{~m}$ n. m. Většina renomovaných autorů doporučuje výšku vyšší. Suchý s Dovalilem (2005) konkrétně od $1500 \mathrm{~m} \mathrm{n}$. m., ale Pupiš s Korčokem $(2006,2007)$ nebo Suslov s Gippentrejterem a Chodolovem (1999) popisují střední stupeň nadmořské výšky od $1300 \mathrm{~m}$ n. m. Tato výška se již překrývá s výškovým údajem dotázaných trenérů. Vezmeme-li v úvahu fakt, že mladý organismus na vysoké zatížení reaguje intenzivněji než dospělý, a že vysoká nadmořská výška je velkým zatižením na oragnismus, můžeme s opatrností dát českým trenérům za pravdu, a souhlasit s nimi, že v dorosteneckém organismu jsou adaptační změny vyvolány již v nadmořské výšce do $1400 \mathrm{~m}$ n. m. Avšak tato domněnka by měla být předmětem dalších studií této problematiky.

Nejčastěji používanou nadmořskou výškou je rozmezí 1000 až 2500 m n. m. (Daniels 1998). Qingzhang Weng (2004) jako optimální výšku pro trénink uvádí 2000 až 2500 m n. m. Reiss (Reiss 1991) tuto výšku snižuje na 1800 až $2400 \mathrm{~m}$ n. m. Podle možností je doporučováno postupné zvyšování nadmořské výšky (Lychatz 1990).

Hypoxické stany žádný z dotázaných nevyužívá a ani využívat nechce. Většina stany řadí mezí nedovolené prostředky zvyšování výkonnosti, především $\mathrm{z}$ etického hlediska. $\mathrm{V}$ odpovědích jsme se setkali s názorem, že se jedná o zakrytí použití dopingu jako takového nebo o komerční záležitost.

Trenéři lyžařů běžců si plně uvědomují vysokou psychickou zátěž plynoucí z pobytu a tréninku ve vyšší nadmořské výšce na svěřence, přičemž není zaručen pozitivní účinek výšky na zvýšení koncentrace hemoglobinu v krvi a zvýšení výkonnosti. Bolek (2008) totiž uvádí, že proces aklimatizace na výšku je velice individuální a asi 30\% - 40\% lidí je velmi těžko aklimatizovatelných. Z toho vyplývá, že ani po opakovaných pobytech ve výšce nezpůsobí kýžené změny v organizmu a při dalším příjezdu do vyšší nadmořské výšky se u jedince projevují stejné problémy.

Odpovědi při osobním rozhovoru a $\mathrm{v}$ př́ípadě e-mailové korespondence se po obsahové stránce výrazně nelišily. Metoda kvalitativního strukturovaného rozhovoru s otevřenými otázkami se ukázala vhodná, nebot' bylo možné od probandů získat informace, které s danou problematikou zdánlivě nesouvisely, avšak při jejich podrobnějším zkoumání přinesly $\mathrm{k}$ řešené problematice nové podnětné informace. Vybraná metodika byla poměrně vysoce časově náročná, a to již v průběhu samotných řízených rozhovorů, zvláště pak při vyhodnocování získaných informací. Trenéři byli od začátku vstřícní a otevření, i když zřejmě určitou roli sehrála osoba tazatele, kterého všichni dobře znají. Čím více dotazovaný tazatele znal, tím více byly odpovědi méně obšírné.

\section{Závěr}

Z výsledků strukturovaných rozhovorů s otevřenými otázkami vyplynulo, že pro běžce na lyžích je příprava ve vyšší nadmořské výšce nedílnou součástí př́ípravy v rámci ročního tréninkového cyklu. Pro mladší kategorie je dostačující výška okolo $1400 \mathrm{~m}$ n. m., která je dostupná v ČR. Pro juniory a dospělé je nutná výška vyšší.

Neexistuje obecně platný model tréninku ve výšce, což potvrdili i dotazovaní, nebot jejich odpovědi se neshodovaly ani v otázce, zda "trénovat dole - bydlet nahoře“ nebo „trénovat nahoře - bydlet dole“. Dotazovaní se v názorech liší i v délce pobytu, resp. vědí, že literatura doporučuje jednadvacetidenní pobyt ve výšce, ale pro náročnost takovéhoto kempu tuto dobu zkracují na 7 - 16 dní, nejčastěji na přibližně 12 dnů a pobyt opakují.

Pro kontrolu efektivity tréninku využívají především odezvy srdeční frekvence, analýzu krve, subjektivní pocity závodníka i objektivní změny stavu organismu.

Výzkum byl podpořen z prostředků výzkumného záměru MSM0021620864 a specifického vysokoškolského výzkumu 2010-261601.

\section{Použitá literatura}

BIGARD, A. X.; A. BRUNET, C. Y.; GUEZENNEC; MONOD H. Skeletal muscle changes after endurance training at high altitude. Journal of Applied Physiology, 1991, vol. 71, s. $2114-2121$. 
BOLEK, E. Adapce na vyšší nadmořskou výšku. In. Současný sportovní trénink. Sborník, Praha, 2008. s. 35 - 38. DANIELS, J. Running formula. Human Kinetics, USA, 1998, s. 287. ISBN 0-88011-735-4.

DOVALIL, J. a kol. Sportovní výkon a trénink ve vyšši nadmořské výšce. Praha : ČOV, 1999.

FIBINGER, I.; NOVÂK, J. Hypoxie jako tréninkový prostředek ve sportovní př́pravě. Praha : ČÚV ČSTV prostřrednictvím Olympia, 1986.

FRIEDMANN, B.; BURTSCH, P. High altitude training: sense, nonsense, trends. Orthopaede, 1997, vol. 26, s. 987 - 992.

FUCHS, U.; REISS, M. Höhentraining: das Erfolgskonzept der Ausdauersportarten (Trainerbibliothek 27). Münster : Philippka, 1990.

GORE, C. J. a kol. Live high: train low increases muscle buffer kapacity and submaximal cycling efficienty. Acta Physiologica Scandinavica, 2001, vol. 173, s. 102 - 112.

GÖRNER, K.; KOMPÁN, J. Vplyv zataženia formou pešej turistiky realizovanej v stredohorskom prostredí na zmeny prejavujúce sa v kardiovaskulárnom systéme turistky. In Acta Universitatis Matthiae Belii : Telesná výchova a šport. Banská Bystrica : Pedagogická fakulta UMB, 2001, roč. 3, č. 3, s. 33 - 38. ISBN 80-8055-612-1.

HAMAR, D.; LIPTÁKOVÁ, J. Fyziológia telesných cvičení. Bratislava : UK, 1998.

HENDL, J. Kvalitativní výzkum: základní metody a aplikace. Praha : Portál, 2005, 408s. ISBN: 80-7367-040-2.

CHOUTKA, M.; URBÁNEK, J. Zásady předolympijské přípravy československých sportovců na olympijské hry v Mexiku. Teor. praxe. těl. vých. 1967, č. 15, s. 552 - 554.

JOKL, E. (editor) Medicine and Sport: Exercise and altitude. Basel : S. K. Karger AG, 1968.

KOBELA, P. Uplatnenie optimálnej tréningovej metódy v príprave 17 - 18 ročných biatlonistov v závislosti na dlžke a miste pobytu v středohoří. Disertační práce. Banská Bystrica : KTHV UMB, 2007.

KORČOK, P.; PUPIŠ, M. V̌setko o chôdzi. Banská Bystrica : FHV UMB, 2006. 236 s. ISBN 80-8083-185-8. LEVINE, B. D.; STRAY - GUNDERSEN, J. High-altitude training and competition. In The Team Physician's Handbook (2nd ed.), edited by Mellion, M. B. , Walsh, W. M. and Shelton, G. L. Philadelphia, PA : Hanley \& Belfus, 1997, s. 186 - 193.

LIU, Y. a kol. Effects of „living high-training low“ on the cardiac functions at sea level. Int. J Sports Med., 1998, s. 380 - 384.

LYCHATZ, S. Tendenzen der trainingsmethodische Entwicklung in der Ausdauersportarten im Olympiazyklus 1985 bis 1988. Leistungssport, 1990, vol. 20, s. 45 - 47.

MADSEN, O. Hypoxia - the „magic pill“ to enhance performance in endurance sports int the 21st century. In Proceedings of the Second Altitude Training sympozium. Flagstaff, 1999.

PARDO, R. O. I. International symposium of altitude training. Granada University (Lectures). Granada : Faculty of Physical Activity and Sport Science, 2008.

PATTON, M. Q. Qualitative evaluation and research methods. Newbury Park and London : Sage, 1990.

PUPIŠ, M.; KORČOK, P. Hypoxia jako súčast športovej prípravy. Banská Bystrica : Univerzita Mateja Bela, FHV, 2007. ISBN: 978-80-8083-495-1

PAUGSCHOVÁ, B.; KOBELA, P.; ŠTULRAJTER, V. Vplyv optimálnej tréningovej metódy v príprave mladých biatlonistov v závislosti na dížke a mieste pobytu v stredohorí. In Čilík, I. a kol. Adaptácia na zataženie $v$ priebehu ročného tréningového cyklu u reprezentantov $v$ atletike a $v$ biatlone. Banská Bystrica : FHV UMB, 2006, s. 80 - 108. ISBN 80-8083-315-X.

QINGZHANG WENG. The Recent Development of Altitude Training in China. China, Beijing : National Institute of Sports Science. In Summary high altitude training symposium. 2004, 19th \& 20th March, Hong Kong Sports Institute, Hong Kong.

REISS, M. Grundlegende probleme der Methodik des Höhentrainings in den Ausdauersportarten. Leistungssport Monster. 1991, roč. 21, vol. 6, s. 27 - 32.

REEVES, J. T. a kol. Oxygen transport dutring exercise at high altitude and the lactate paradox. In Exercise and sport science reviews, 1992, s. 257 - 296.

SHERRY, E.; WILSON, S. F. Oxford handbook of sports medicine. Oxford: University Press, 1998. 
SUCHÝ, J.; DOVALIL, J. Adaptace a problematika tréninku v hypoxickém prostředí. NŠC revue 1, Bratislava, 2005, s. 19 - 22.

SUCHÝ, J.; DOVALIL, J. Problematika tréninku ve vyšší nadmořské výšce $\mathrm{z}$ pohledu trenérů. Phys. Educ. Sport, Bratislava, 2009, roč. 18. vol. 3 - 4, s. 4 - 8, ISSN: 1335-2245.

SUCHÝ, J.; DOVALIL, J.; PERIČ, T. Současné trendy tréninku ve vyšší nadmořské výšce. Česká kinantropologie, Praha, 2009, č. 13, s. 38 - 53.

SUSLOV, F. P. Basic principles of training at high altitude. In New Studies in Athletics. IAAF 1994, vol. 2, s. $45-49$.

SUSLOV, F. P.; GIPPENTREJTER, E. B.; CHOLODOV, Ž. K. Sportivnaja trenirovka v uslovijach srednegorja. Moskva, 1999, s. $21-44$.

ŠTULRAJTER, V.; KOBELA, P.; FALŤAOVÁ, J. Pobyt a tréning v stredohorí a ich vplyv na hematologické ukazovatele a trénovanost' biatlonistov. In Telesná výchova a šport. 2001, č. 4, s. 30-33.

TERRADOS, C. N. L' allenamento in altitudine. Scuola dello Sport, 1995, č. 14, s. 14 - 22.

VANĚK, M. Vliv nadmořské výšky Mexico City na psychickou složku sportovní výkonnosti. Teor. praxe. Těl. Vých., 1968, č. 16, s. 408 - 501.

WEINECK, J. Optimales Training. Balingen.: Spitta Verlag : GmbH, 1997.

WILBER, L.R. Altitude training and Athletic perfomance. Champaign : Human Kinetics, 2004.

ZÁKLADNÍ METEOROLOGICKÉ PRVKY A JEJICH KLIMATOLOGICKÉ CHARAKTERISTIKY: dostupné na: www.geogr.muni.cz/archiv/vyuka/MeteoKlima/met_student3.pdf [on line, cit. 3. 6. 2010] 